\title{
EXTRACTION AND QUANTITATIVE DETERMINATION OF ASCORBIC ACID FROM BANANA PEEL MUSA ACUMINATA 'KEPOK'
}

\author{
KHAIRUl ANWAR MOHAMAd SAID, ZAINAD RADZI, IBRAHIM YAKUB, \\ AND MOHAMED AFIZAL MOHAMED AMIN \\ Department of Chemical Engineering and Energy Sustainability, \\ Faculty of Engineering, Universiti Malaysia Sarawak, 94300, \\ Kota Samarahan, Sarawak, Malaysia. \\ I'mskanwar@feng.unimas.my, ${ }^{2}$ zainabradzi@gmail.com, ${ }^{3}$ yibrahim@feng.unimas.my, \\ ${ }^{4}$ mamafizal@feng.unimas.my \\ (Received: 14 Aug. 2015; Accepted: 03 Dec. 2015; Published on-line: 30 Apr. 2016)
}

\begin{abstract}
This paper discusses the extraction of an antioxidant compound, which is ascorbic acid or vitamin $\mathrm{C}$, from a banana peel using an ultrasound-assisted extraction (UAE) method. The type of banana used was Musa acuminata also known as "PisangKepok" in Malaysia. The investigation includes the effect of solvent/solid ratio $(4.5,5 \mathrm{~g}$ and $10 \mathrm{ml} / \mathrm{g})$, sonication time $(15,30$ and $45 \mathrm{mins})$ and temperature variation (30 , 45 and $60^{\circ} \mathrm{C}$ ) on the extraction of ascorbic acid compounds from the banana peel to determine the best or optimum condition of the operation. Out of all extract samples analyzed by redox titration method using iodine solution, it was found that the highest yield was $0.04939 \pm 0.00080 \mathrm{mg}$ that resulted from an extraction at $30^{\circ} \mathrm{C}$ for $15 \mathrm{mins}$ with $5 \mathrm{ml} / \mathrm{g}$ solvent-to-solute ratio.
\end{abstract}

ABSTRAK: Kertas kajian ini membincangkan kaedah mengekstrak antioksida khususnya asid askorbik atau vitamin $\mathrm{C}$ daripada kulit pisang melalui teknik ultrasonik (UAE). Jenis pisang yang dipilih sebagai bahan kajian ialah Musa acuminata, sejenis pisang yang digunakan dalam masakan. Ia juga dikenali sebagai pisang kepok di Malaysia. Kajian kali ini mengetengahkan tindakbalas nisbah pelarut/pepejal $(4.5,5 \mathrm{~g}$ dan $10 \mathrm{ml} / \mathrm{g}$ ), masa proses ultrasonik $(15,30$ and $45 \mathrm{~min})$ dan perubahan suhu $\left(30,45\right.$ and $\left.60^{\circ} \mathrm{C}\right)$ ke atas kadar ekstrak asid askorbik daripada kulit pisang bagi menentukan tindakbalas optimum didalam proses ini. Selepas analisis dibuat melalui kaedah titrasiredoks, didapati bahawa hasil yang tertinggi dari segi kadar ekstrak asid askorbik adalah $0.04939 \pm 0.00080 \mathrm{mg}$ pada catatan suhu $30^{\circ} \mathrm{C}$ untuk 15 minit dengan pelarut/ bahan larut $5 \mathrm{ml} / \mathrm{g}$.

KEYWORDS: Musa acuminata; Ultrasound-assisted extraction; Vitamin C; Redox titration

\section{INTRODUCTION}

Banana is one of the main crops in the world that has significance to humans for its nutrition and mineral contents. It must have been one of the first known tropical crops since there are records of it being in cultivation 4000 years ago [1]. According to [2], edible bananas originated from Melesia, a biogeographical region consisting of the primary centre including Malaysia, Indonesia, Philippines and New Guinea as well as the secondary centre which is India.

As far as banana is concerned, there are two type of wild banana originally from South East Asia: Musa acuminata Colla (AA) and Musa balbisiana Colla (BB) where the 
difference between both types is mainly the cultivation method [3]. Musa acuminata is categorized as highly polymorphous where the growth is in clumps while Musa balbisiana Colla (BB) usually grows as a plant with a massive trunk [4]. Bananas are divided into three categories; desert banana, plantain and cooking banana [4]. Desert banana is usually associated with Musa acuminata from triploid character for example AAA whereas plantain and cooking banana originated from a hybrid of Musa acuminata and Musa balbisiana. Hybrid banana also has triploid character from AA x BB which brings plantain character to Musa AAB while cooking banana is known as Musa ABB [5]. The main difference between dessert banana and plantain or cooking banana is pulp/flesh. Plantain/cooking banana requires cooking before consumption and its pulp has more starch and less sugar. The only similarity between them is that plantain and cooking banana look very similar to unripe desert banana although it (plantain/cooking banana) usually has larger size [6].

Every part of a banana plant has its own usage from a good source of nutrients to religious ceremonies. In Africa and Asia, banana fruit is a source of starch staple food and dessert bananas are also a main cash crop in many developed and developing countries [7]. Their contribution to human health is due to its great medicinal value. Banana fruit is claimed to prevent anemia, regulate blood pressure, prevent constipation, cure heartburns and prevent stroke [8]. Even the leaves are used as food wrappings and plates for their pleasant smell [9].

Several studies have found that banana pulp and peel contain various high value nutritional use in pharmaceutical industries for instances vitamins (A, B, C and E), $\beta$ carotene and phenolic compounds such as gallocatechin [10], dopamine [11], lignin and tannins [12] and phytosterols and triterpenes such as cycloeucalenol and cycloartenol [13]. Ascorbic acid also known as vitamin $\mathrm{C}$ is an organic compound with physical appearance of white solid while sometime has yellowish color for impure samples. Ascorbic acid is important to living beings where animals are able to self-synthesise it from glucose while human beings fulfill ascorbic acid needs from nutritional supplement or fruit [14]. Several methods have been developed and utilized to quantify ascorbic acid. Among them is the classic method known as volumetric method which required titration of an oxidant solution to ascorbic acid [15]. There are a variety of oxidant solution such as potassium iodate [16] and bromate [17]. Another method is by utilizing spectrophotometer to determine oxidation of ascorbic acid to dehydroascorbic acid where the absorbance spectrum is set at $450 \mathrm{~nm}$. This method requires a reducing agent such as $\mathrm{Cu}(\mathrm{II})$-neocuproine complex which later is reduced to $\mathrm{Cu}(\mathrm{I})$-bis(neocuproine) when mixed with ascorbic acid [18]. Apart of using $\mathrm{Cu}$ (II)-neocuproine complex, there are other methods that utilize the spectrophotometrical determination but use different compounds, for instance iodine [19] and chemiluminescence [20].

Due to the consumer demand for products from natural sources, the economic impact of plant-based extracts especially for food, nutraceuticals, cosmetics, flavors or fragrances, and pharmaceutical industry has developed in the last few years. Extraction technology like ultrasonic-assisted extraction and many other methods are usually used to fulfill the demands. Conventional method such as boiling or hot water extraction has been utilized before any other extraction methods exist in order to extract antioxidants, unfortunately hot water extraction method has several disadvantages mainly antioxidant degradation due to high temperature and oxidation as well as the long extraction period [21]. In recent years, the emergence of new extraction processes for instance microwave assisted extraction [2224], ultrasonic assisted extraction [21,25-27] and supercritical fluid extraction [28-30] has helped to reduce the extraction period and at the same time reduce degradation rate of antioxidant. Among these, ultrasonic assisted extraction has three qualities that other 
methods lack which are easier procedure, inexpensive and this process can also be conducted with no external heat i.e. at troom temperature [31]. Ultrasound can be defined as a sound wave with frequency higher than $18 \mathrm{kHz}$. A lot of studies have been done on the application of both high and low power ultrasound [32]. The different intensity of powers has different usage in various fields. Low power ultrasound are mainly applied in medical ultrasonography while high power ultrasound have numerous uses such as ultrasonic welding, degassing of solutions, defect detection and sonochemistry [32]. An important phenomenon associated with power ultrasound is called cavitation bubbles. When liquids are sonicated at high ultrasound intensities, the sound waves that propagate into the liquid media causes alternating high-pressure (compression) and low pressure (rarefaction) cycles, where rates are dependent on the frequency [33]. The bubbles are produced during rarefaction cycle of the wave when the liquid structure are broken resulting in the formation of tiny voids which collapse in the compression cycle [34]. In early application of ultrasonic techniques, ultrasonic cleaning bath has been introduced into metallurgy and chemical laboratories in the 1960's and considering how soiled glassware was being cleaned and immiscible organic solvents dispersed in aqueous detergent, it was not surprising that is being used by chemists to enhance chemical reactivity [34]. Until today, sonochemistry has been an ongoing investigation for over 50 years [35].

Some of the reports on the extraction of banana products using hot water extraction methods have been published. These state that the optimum condition for hot water extraction methods for extracting banana juice were $95^{\circ} \mathrm{C}$ for 120 mins [36] while others also choose to proceed with this methods for a duration of 120 mins [37]. Ascorbic acid is a highly sensitive material subjected to a number of processing conditions and is also a thermolabile substance [38]. Furthermore, in order to understand ascorbic acid degradation; it follows two mechanism pathways aerobic or anaerobic which are related closely to processing conditions $[38,39]$. In this study, a temperature range from $30^{\circ} \mathrm{C}$ until $60^{\circ} \mathrm{C}$ are chosen for extraction in order to reduce ascorbic acid degradation resulting from heat. Subsequent, solid to solvent ratio is also an important parameter related to extraction and by knowing the optimized ratio could help reduce wastage of solvent and reduced bulk process. For instances, ratio of 1:10 in extraction of piperine from Piper longum was considered the optimum because at a higher ratio, only small increment of yield was observed [40]. With this knowledge, solid to solvent ratio of $(4.5,5 \mathrm{~g}$ and $10 \mathrm{ml} / \mathrm{g})$ have been used. Finally, extraction time is usually based on the process cost. The best process must be operated with minimal energy and shorter time at each extraction cycle. Based on several studies, it can be concluded that acceptable time for extraction of antioxidant ranges from 3 to 45 minutes where optimum time usually falls within 30 to 40 minutes [40-44]. With this in mind, extraction times of $(15,30$ and 45 mins) have been used.

Therefore, considering the promising application of this method to extract ascorbic acid, there is a great potential for using ultrasonic assisted extraction method to extract ascorbic acid from banana pulp. The aim of this study is to test feasibility of extracting ascorbic acid using ultrasonic cleaning bath, to investigate effects of different parameters towards extraction of ascorbic acid and finally to determine optimum extraction conditions using ultrasonic cleaning bath.

\section{METHODOLOGY}

\subsection{Materials}

Banana from species Musa acuminata 'Kepok' were obtained from the Kota Samarahan market in the state of Sarawak, Malaysia. The maturity of bananas was observed visually 
which can be described as follows; the bananas were fully ripe and have yellow skin. Besides, methanol 99.8\% (Sigma-Aldrich), iodine 99.9\% anhydrous (Sigma-Aldrich), potassium iodide anhydrous (ACS reagent) used was of analytical grade while vitamin C was obtained from Abbot Laboratories, USA.

\subsection{Sample Preparation}

Initially, all bananas were washed with municipal tap water to remove soil or dust. Then cleaned bananas were peeled and the peels were collected for sampling. The peels were freeze-dried using FreeZone ${ }^{\circledR}$ 4.5 Liter Freeze Dry Systems (Labconco, USA) which was set to run automatically at a pressure and temperature of $7 \mathrm{bar}$ and $-30^{\circ} \mathrm{C}$ respectively before sliced into smaller pieces using IKA A11 Basic Analytical mill (Sigma-Aldrich) to a fine powder form.

\subsection{Extraction of Antioxidant}

The ultrasonic-assisted extraction of ascorbic acid from dried banana peels were executed in an ultrasonic bath ( $\mathrm{S} 900 \mathrm{H}$, Elmasonic Elma Schmidbauer GmbH, Germany) at a constant power of $2000 \mathrm{~W}$ and ultrasonic frequency of $37 \mathrm{kHz}$. The extraction was conducted with different solvent-to-solute ratio, temperature and sonication time. The solvent used was $60 \%$ methanol. It must be noted that single electron transfer and hydrogen atom transfer are affected by the type and polarity of the solvent used to extract ascorbic acid from the banana peel [45].

Fine banana powders (110 g) were used for these experiments. The experiments were conducted with a solvent/solid ratio of $4.5 \mathrm{ml} / \mathrm{g}, 5 \mathrm{ml} / \mathrm{g}$ and $10 \mathrm{ml} / \mathrm{g}$. The samples in the beaker were then transferred to a $250 \mathrm{ml}$ sample bottles and were placed in the ultrasonic bath to be extracted at different experimental conditions. Sonication time of extraction was varied at 15,30 and 45 mins while the temperature at $30^{\circ} \mathrm{C}, 45^{\circ} \mathrm{C}$ and $60^{\circ} \mathrm{C}$. Extraction temperature was controlled by a built-in function of ultrasonic bath. After that, the crude extracts were filtered using Whatman filter papers before the extracts were heated until a significant amount of methanol solvent evaporated which was collected to estimate the oil yield. The extracts were then titrated with Iodine to determine the ascorbic acid or vitamin C content.

\subsection{Quantification of Ascorbic Acid}

A $500 \mathrm{mg}$ vitamin C tablet was used for the construction of the standard curve. The single tablet was dissolved in $200 \mathrm{ml}$ distilled water where $1 \mathrm{ml}$ aliquot was taken using a pipette out of the sample solution and transferred into a $250 \mathrm{ml}$ conical flask. One milliliter of starch indicator solution was added and the flask was filled to $200 \mathrm{ml}$ with distilled water.

The sample was titrated with $0.005 \mathrm{~mol} / \mathrm{l}$ iodine solution. The endpoint of the titration was identified as the first permanent trace of a dark blue-black colour due to the starchiodine complex. It was repeated with further aliquots of sample solution until concordant results were obtained. Titration was repeated three times and the average value was taken.

Sample $(1 \mathrm{ml})$ was diluted in a $250 \mathrm{ml}$ conical flask with distilled water filling to 200 $\mathrm{ml}$. Then, $50 \mathrm{ml}$ aliquot of the solution was taken for titration and mixed with $1 \mathrm{ml}$ starch solution and diluted again with distilled water to $200 \mathrm{ml}$. The sample was again titrated with $0.005 \mathrm{~mol} / 1$ iodine solution. The end point of the titration was identified as the first permanent trace of a dark blue-black colour due to the starch-iodine complex. The titration was repeated three times with the same amount of aliquots of sample solution until concordant results were obtained and the average volume of iodine used was calculated. 


\section{RESULTS AND DISCUSSION}

\subsection{Effect of Sonication Time on Vitamin C Yield}

Figure 1 shows the effect of sonication time; 15, 30 and $45 \mathrm{mins}$, solvent/solid ratio; $4.5 \mathrm{ml} / \mathrm{g}, 5 \mathrm{ml} / \mathrm{g}, 10 \mathrm{ml} / \mathrm{g}$, and extraction temperature: $30^{\circ} \mathrm{C}$ on the extraction yield of Vitamin $\mathrm{C}$ from banana peel. The methanol concentration: used throughout this experiment is kept at a constant concentration which is $60 \%$. At $30^{\circ} \mathrm{C}$, the yield decreases as the time is extended from 15 to 30 mins. This may happen because longer sonication time can affect the extraction results since the extra sonication can degrade the quality of extracts [31]. The increase of yield occurred as the time increased to 45 mins. At 15 mins, $0.04939 \pm 0.00080$ $\mathrm{mg}$ of yield were obtained from extracts which is the highest yield throughout the experiment whereas at $30 \mathrm{mins}$ and $45 \mathrm{mins}, 0.03046 \pm 0.00138 \mathrm{mg}$ and $0.03416 \pm 0.00080$ $\mathrm{mg}$ were obtained respectively. Both are lower than the yield at 15 mins by $61.68 \%$ and $69.16 \%$ correspondingly. In conjunction with sudden rise of extraction yield at 15 mins for $4.5 \mathrm{ml} / \mathrm{g}$ solvent-solid ratio, there are few other researchers experience of the same occurrence when utilizing ultrasonic method. All agree that optimum extraction time falls between 15 to 20 mins and further period of ultrasonication will result with a decrease of extraction yield [46-48]. There are two phases of extraction process which can also be indicated by extraction time: the first phase involve dissolution of soluble on the surface of sample followed by the second phases that focus on mass transfer from within the sample either through osmosis or diffusion [49]. Based on this two phases, it is believed that 4.5 $\mathrm{ml} / \mathrm{g}$ solvent-solid ratio has lowest saturation of ascorbic acid which enable two phases of extraction whereas other configuration suffer from high saturation of ascorbic acid which prevents high mass transfer rate and after 20 mins has passed, apparent ascorbic acid degradation has started to occur which in the end results in a decrease of extraction yield.

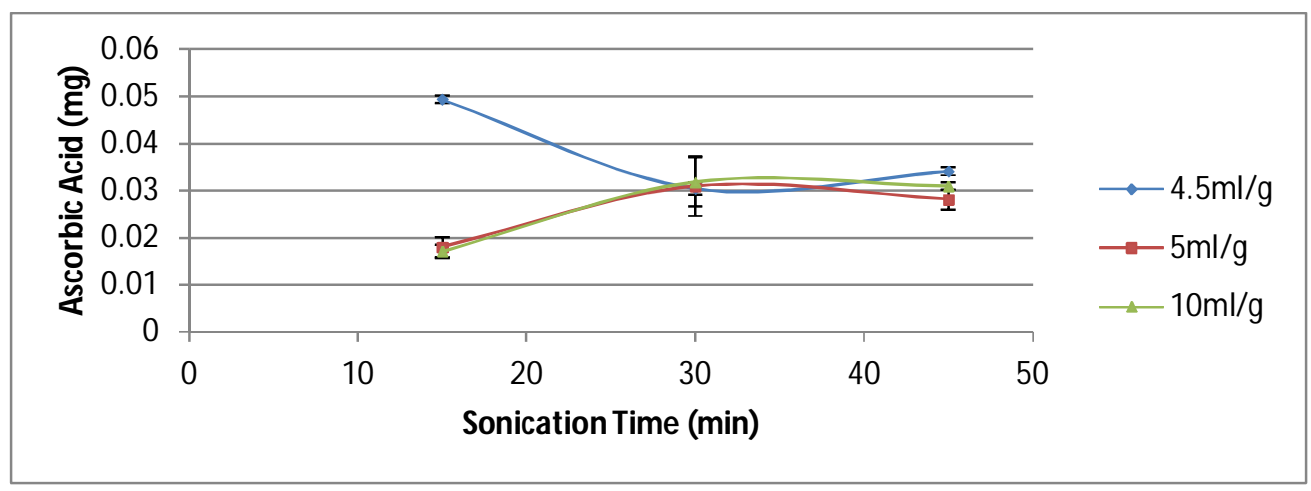

Fig. 1: Effect of ultrasonication time; 15, 30 and $45 \mathrm{mins}$, solvent/solid ratio; $4.5 \mathrm{ml} / \mathrm{g}$, $5 \mathrm{ml} / \mathrm{g}, 10 \mathrm{ml} / \mathrm{g}$, and extraction temperature: $30^{\circ} \mathrm{C}$ on the extraction yield of vitamin $\mathrm{C}$ from banana peel. Methanol concentration: $60 \%$.

At $30^{\circ} \mathrm{C}$ (Fig. 1) and solvent/solid ratio of $4.5 \mathrm{ml} / \mathrm{g}$ and $5 \mathrm{ml} / \mathrm{g}$ both indicate that the yield levitates as the time is extended from 15 to 30 mins. However, the increase is immediately diminished when sonication time is extended to $45 \mathrm{mins}$. This is also true for the yield obtained at $45^{\circ} \mathrm{C}$ (Fig. 2) and solvent/solid ratio of $10 \mathrm{ml} / \mathrm{g}$. At $60^{\circ} \mathrm{C} \mathrm{(Fig.} \mathrm{3),} \mathrm{all}$ three ratios shows the same pattern with the same temperature changes. In the view of time usage, it is not recommended to exceed 30 mins.

Sonication time plays an important part in this extraction too. As discussed earlier, longer sonication time causes less ascorbic acid yield because the cavitation depletes as the 
sonication time increases. The optimum time found in this study indicates the lowest time experimented. Lesser time for extraction is feasible and practical for this extraction to be done at an industrial scale.

Figure 2 shows the yield of ascorbic acid trend for extraction temperature $45^{\circ} \mathrm{C}$ and solvent to solid ratio of 4.5 to $10 \mathrm{ml} / \mathrm{g}$, in general the results show an increment of all parameter setting until 30 minute which show sudden drop for $10 \mathrm{ml} / \mathrm{g}$ solvent-solid ratio from $0.042 \mathrm{mg}$ to $0.026 \mathrm{mg}$ whereas other configuration experience equilibrium trend. Rapid decrease of extraction yield for $10 \mathrm{ml} / \mathrm{g}$ solvent-solid ratio was caused by saturation of ascorbic acid [47,50]. The same occurrence has been observed with ultrasonic assisted extraction of phenolic compound from sugarcane where the extraction yield diminishes after 30 mins and increasing for a period of 10 mins within time frame of 20 to 30 mins [51]. Another possibility that might cause yield losses at $10 \mathrm{ml} / \mathrm{g}$ was oxidation of ascorbic acid. It was believed that longer extraction period has exposed more oxygen to the extract and therefore incite oxidation process [52].

In a different occasion, extraction of piperine from Piper longum show equilibrium yield after 18 mins of extraction with yield fluctuating within 4 to $5 \mathrm{mg} / \mathrm{g}$ [40]. This findings was found to agree with the current yield in Fig. 2 for 4.5 and $5 \mathrm{ml} / \mathrm{g}$ solvent-solid ratio which show small increase of yield in span of 15 to $45 \mathrm{mins}$ of extraction. At $5 \mathrm{ml} / \mathrm{g}$ solventsolid ratio, the lowest point was 0.044 for $15 \mathrm{mins}$ and peak at $0.045 \mathrm{ml} / \mathrm{g}$ at the end of the extraction process. Otherwise, $4.5 \mathrm{ml} / \mathrm{g}$ solvent-solid ratio show $0.009 \mathrm{mg}$ increase between 15 to 30 mins of extraction time and settle at 0.031 at 45 mins of extraction. Each point of yield for $4.5 \mathrm{ml} / \mathrm{g}$ solvent-solid ratio are $0.019,0.028$ and $0.031 \mathrm{mg}$ corresponding to 15,30 and 45 mins of extraction.

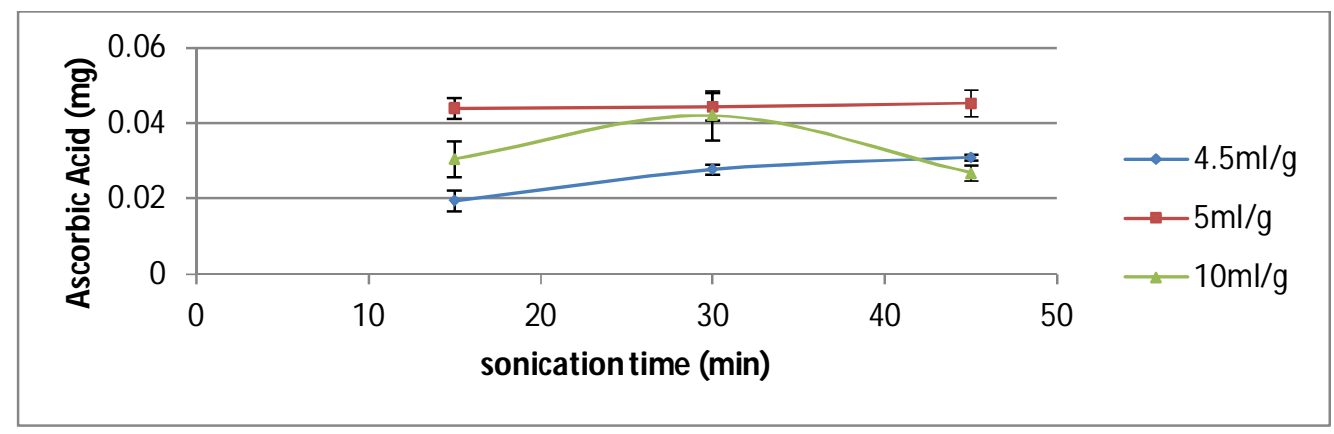

Fig. 2: Effect of ultrasonication time; 15, 30 and $45 \mathrm{mins}$, solvent/solid ratio; $4.5 \mathrm{ml} / \mathrm{g}$, $5 \mathrm{ml} / \mathrm{g}, 10 \mathrm{ml} / \mathrm{g}$, and extraction temperature: $45^{\circ} \mathrm{C}$ on the extraction yield of vitamin $\mathrm{C}$ from banana peel. Methanol concentration: $60 \%$.

Figure 3 shows the effect of extraction period against ascorbic acid yield at 4.5, 5 and $10 \mathrm{ml} / \mathrm{g}$ solvent-solid ratio and $60^{\circ} \mathrm{C}$. At this configuration, solvent-solid ratio of $10 \mathrm{ml} / \mathrm{g}$ reach equilibrium in term of ascorbic acid yield after 30 mins of extraction where the yield fluctuates within interval of 0.043 to $0.045 \mathrm{mg}$. Otherwise, $5 \mathrm{ml} / \mathrm{g}$ solvent-solid ratio has reached a constant yield at $0.027 \mathrm{mg}$ after $15 \mathrm{mins}$ of extraction while $4.5 \mathrm{ml} / \mathrm{g}$ experiences a sudden drop of ascorbic acid yield after 30 mins from $0.026 \mathrm{mg}$ to $0.020 \mathrm{mg}$. Solute equilibrium in this work was a constant yield of ascorbic acid can only be achieved by principles of saturation. According to the literature [53], saturation was achieved when amount of solvent has restricted any further process to extract the remaining solute from samples. According to mass transfer principles, higher diffusion can be achieved when there was high driving force which solely relate to concentration gradient. Higher concentration gradient can only be achieved when quantity of solvent is higher than sample weight $[53,54]$. 
As far as the $10 \mathrm{ml} / \mathrm{g}$ solvent-solid ratio is concerned, this configuration has the highest solvent volume per gram of samples and its yield was consistent to mass transfer principles that state the increase of yield with the increase of solvent quantity.

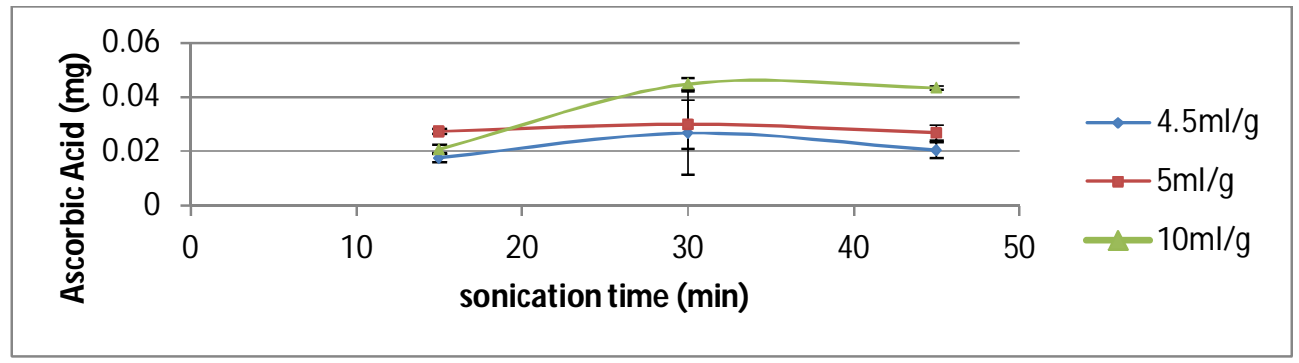

Fig. 3: Effect of ultrasonication time; 15, 30 and $45 \mathrm{mins}$, solvent/solid ratio; $4.5 \mathrm{ml} / \mathrm{g}, 5$ $\mathrm{ml} / \mathrm{g}, 10 \mathrm{ml} / \mathrm{g}$, and extraction temperature: $60^{\circ} \mathrm{C}$ on the extraction yield of vitamin $\mathrm{C}$ from banana peel. Methanol concentration: $60 \%$.

\subsection{Effect of Temperature on Vitamin C yield}

Figure 4 shows the effect of temperature on the extraction yield of vitamin $\mathrm{C}$ from banana peel. Using solvent/solid ratio of $4.5 \mathrm{ml} / \mathrm{g}$ and sonication time of $15 \mathrm{mins}$, the extraction yield of Vitamin $\mathrm{C}$ decreases as temperature was increased from $30^{\circ} \mathrm{C}$ to $60^{\circ} \mathrm{C}$. The temperature was manually changed by the built-in functions of the ultrasonic bath.The basis of choosing $4.5 \mathrm{ml} / \mathrm{g}$ solvent-solid ratio over other parameter was based on amount of yield where the highest yield recorded was $0.049 \mathrm{mg}$ at $4.5 \mathrm{ml} / \mathrm{g}, 30^{\circ} \mathrm{C}$ and $15 \mathrm{mins}$ of extraction.

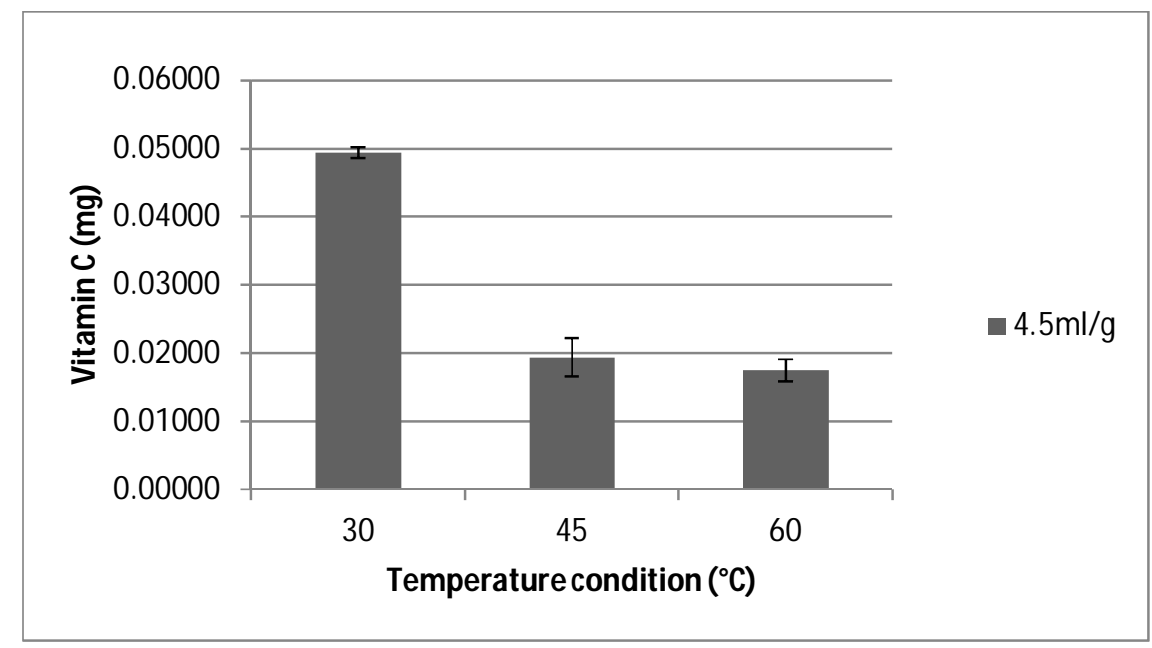

Fig. 4: Effect of temperature on Vitamic $\mathrm{C}$ yield at $4.5 \mathrm{ml} / \mathrm{g}$ of solvent/solid ratio.

The highest yield was obtained at $30^{\circ} \mathrm{C}$ with the value of $0.04939 \pm 0.00080 \mathrm{mg}$ which was $60.7 \%$ higher than yield at $45^{\circ} \mathrm{C}$. At $30^{\circ} \mathrm{C}$, the mass transfer has improved due to the increasing solubility of Vitamin $\mathrm{C}$ and the decreasing viscosity of the solvent.

The yield at $45^{\circ} \mathrm{C}$ is $60.75 \%$ less than the yield at $30^{\circ} \mathrm{C}$ while at $60^{\circ} \mathrm{C}$, it is lower by $64.49 \%$. This may be caused by the degradation of vitamin $\mathrm{C}$ at elevated temperature where the ultrasonic probe causes an increase in the bulk temperature [55]. 
When the amplitude is higher, the temperature increases faster and it can go beyond the desired temperature in a short period of time. The most apparent effects that can occur are the degradation of compounds tested, and the volatilization of low volatile analytes. In addition, the increase of temperature changes the physical characteristics of the liquid media in such a way that it affects the ultrasonic transmission with no cavitation achieved, which is a phenomenon known as decoupling [56,57].

As temperature is a very important parameter, it must be controlled but it is not easy to achieve the desired value. This has also been observed for ultrasonic assisted extraction of Salvia officinalis where the result obtained show that it is crucial to accurately control the extraction temperature when ultrasound is used for it constantly generates heat [58]. On the other hand, lower heat supply in addition to the heat generated by ultrasound calls for a lesser energy use in the industry which could attract more interest on its investment [58].

\subsection{Effect of Solvent-to-Solid Ratio on Vitamin C Yield}

Figure 5 displays the effect of solvent/solid ratio on the extraction yield of Vitamin C from banana peel. The experiment was carried out with a constant methanol concentration of $60 \%$, extraction temperature of $30^{\circ} \mathrm{C}$ and sonication time of 30 mins. The yield shows an increasing trend as the solvent/solid ratio increases. At $4.5 \mathrm{ml} / \mathrm{g}$ of solvent/solid ratio, the extraction yielded $0.03046 \pm 0.00138 \mathrm{mg}$ of vitamin $\mathrm{C}$ and a slight increase to $0.03093 \pm$ $0.00524 \mathrm{mg}$ can be seen as the ratio was increased to $5 \mathrm{ml} / \mathrm{g}$. It increased further to 0.03185 $\pm 0.00635 \mathrm{mg}$ at $10 \mathrm{ml} / \mathrm{g}$ of solvent/solid ratio.

A larger solvent volume can dissolve targeted components more efficiently and therefore resulted in an enhancement of the extraction yield. The observation therefore obeys the mass transfer principle, where the driving force during the mass transfer was the concentration gradient between the solid and bulk liquid in which was escalated with a higher solvent/solid ratio usage $[59,60]$.

At $60^{\circ} \mathrm{C}$, the vitamin $\mathrm{C}$ yields also exhibited increasing value when the solvent/solid ratio was increased. From Fig. 5, it can be seen that extracts obtained by using $4.5 \mathrm{ml} / \mathrm{g}$ contained $0.02677 \pm 0.00212 \mathrm{mg}$ vitamin $\mathrm{C}$ and had $10.76 \%$ more that was 0.03000 $\pm 0.00890 \mathrm{mg}$ at $5 \mathrm{ml} / \mathrm{g}$ ratio. The highest yield obtained was when $10 \mathrm{ml} / \mathrm{g}$ solvent was used that resulted with $0.04477 \pm 0.01525 \mathrm{mg}$ vitamin $\mathrm{C}$. This shows that the extraction yields more compounds with more solvent used.

Ultrasound-extraction at $30^{\circ} \mathrm{C}$ yielded higher ascorbic acid at any solvent/solid ratio in comparison to the extraction at $60^{\circ} \mathrm{C}$. For instance at $4.5 \mathrm{ml} / \mathrm{g}$ solvent, the difference between the yield values of ascorbic acid at $30^{\circ} \mathrm{C}$ and $60^{\circ} \mathrm{C}$ were $12.12 \%$ and $2.99 \%$ at 5 $\mathrm{ml} / \mathrm{g}$.

This substantiated the findings discussed in section 3.2 that the decrease in vitamin $\mathrm{C}$ was caused by thermal effects as it is a sensitive molecule that is altered at temperature above $60^{\circ} \mathrm{C}$. The presence of ultrasound had caused the temperature to increase beyond the targeted temperature, so lower heating supply is needed for a particular extraction temperature. The phenomenon where decreasing acoustic cavitation bubbles created by the ultrasound had also caused the yield to decrease at $60^{\circ} \mathrm{C}$. Therefore, even though the yield increased with increasing solvent-to-solid ratio, the yield had a slight decrease when the temperature was increased. 


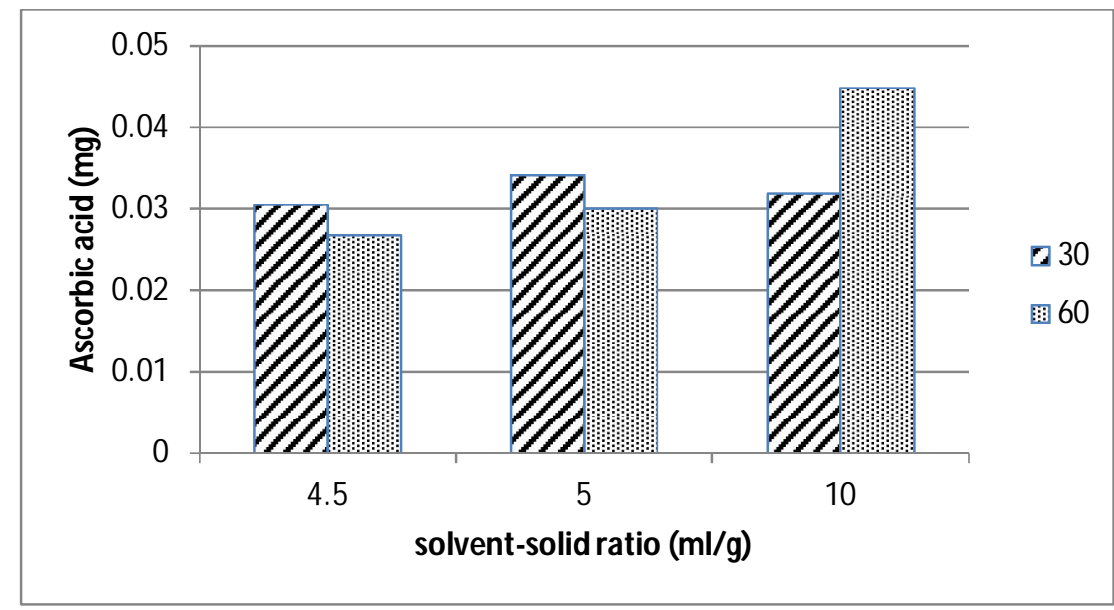

Fig. 5: Comparison between yields at $30^{\circ} \mathrm{C}$ and $60^{\circ} \mathrm{C}$, solvent to solid ratio of $4.5,5$ and $10 \mathrm{ml} / \mathrm{g}$ and sonication time of $30 \mathrm{mins}$.

\section{CONCLUSION}

The results obtained from this study indicate the feasibility of extraction of Vitamin C from banana peel using ultrasonic assisted extraction method. Based on all extract samples analyzed by redox titration method, it was found that the highest yield was $0.04939 \pm$ $0.00080 \mathrm{mg}$ obtained at the temperature $30^{\circ} \mathrm{C}$, sonication time of $15 \mathrm{mins}$ and solvent/solid ratio of $5 \mathrm{ml} / \mathrm{g}$ amongst other conditions. Of the three parameters chosen, it was found that temperature and sonication period have significant effect on the extraction yield of ascorbic acid from banana peel. The main idea of utilizing ultrasonic assisted extraction is to provide mechanical disruption to the cell structure without effect of heat. Ultrasonic extraction is providing cavitation effect towards the banana peel samples causing it to release the extract or contents.

Long extraction period followed by temperature more than $30^{\circ} \mathrm{C}$ will increase the possibility of oxidation of ascorbic acid and degradation of ascorbic acid due to heat. Therefore, it is important to choose efficient extraction condition i.e. extraction temperature, time period and ratio of solvent to solid in order to maintain and preserve extraction yield.

\section{ACKNOWLEDGEMENT}

The author gratefully acknowledges Universiti Malaysia Sarawak and Ministry of Education Malaysia for technical and financial support through Research Acculturation Grant Scheme (RAGS) no: E14099/F02/69/943/2012(44).

\section{REFERENCES}

[1] Allen BM. (1975) Common malaysian fruits, Longman Malaysia Sdn. Bhd., Selangor.

[2] N.W. Simmonds, K. Shepherd (1955), The taxonomy and origins of the cultivated bananas., J. Linn. Soc. London, Bot. 55:302-312.

[3] Shian TE, Abdullah A, Musa KH, Maskat MY, Ghani MA. (2012) Antioxidant properties of three banana cultivars (Musa acuminata "Berangan",'Mas' and "Raja") extracts. Sains Malaysiana, 41:319-324.

[4] Aurore G, Parfait B, Fahrasmane L. (2009) Bananas, raw materials for making processed food products. Trends Food Sci. Technol. 20:78-91.

[5] Hassan NMM. (2004) Banana R \& D in Malaysia: Update and highlights, in: V.D.B.I.\& 
M.M.A.G. Molina A. B., Eusebio J.E., Roa V.N. (eds.), Adv. Banan. Plantain R D Asia Pacific, vol. 12, INIBAP, Jakarta.

[6] Happi Emaga T, Andrianaivo RH, Wathelet B, Tchango JT, Paquot M. (2007) Effects of the stage of maturation and varieties on the chemical composition of banana and plantain peels. Food Chem., 103:590-600.

[7] Abdullah FC, Yap LV, Mohammad Wali Y, Sundaraj HS, Khamis S. (2011) Peeling the Scientific Facts of Banana. International Islamic Academy for Life Sciences \& Biotechnology, Universiti Selangor., Shah Alam, Selangor. pg 9-24.

[8] Ahnwange B, Ugye T, Nyiaatagher TD. (2009) Chemical composition of Musa sapientum (banana) peels. Electron. J. Environ. Agric. Food Chem., 8:437-442.

[9] Orhan I. (2001) Biological activities of Musa species. J. Fac.Farm., 30:39-50.

[10] Someya S, Yoshiki Y, Okubo K. (2002) Antioxidant compounds from bananas (Musa cavendish). Food Chem., 79:351-354.

[11] Kanazawa K, Sakakibara H. (2000) High content of dopamine, a strong antioxidant, in Cavendish banana. J. Agric. Food Chem., 48:844-848.

[12] Lim YY, Lim TT, Tee JJ. (2007) Antioxidant properties of several tropical fruits: A comparative study. Food Chem., 103:1003-1008.

[13] Knapp FF, Nicholas HJ. (1969) The sterols and triterpenes of banana peel. Phytochemistry, 8:207-214.

[14] Sebastian M, Padayatty J, Sun H, Wang Y, Riordan HD, Hewitt SM, Katz A, Wesley RA, Levine M. (2004) Implications for Oral and Intravenous Use, Annals of Internal Medicine 140:533-537.

[15] Fadhel D. (2012) Spectrophotometric determination of ascorbic acid in aqueous solutions. Jnus. Org., 15:88-94.

[16] Pisoschi AM, Pop A, Serban AI, Fafaneata C. (2014) Electrochemical methods for ascorbic acid determination, Electrochim. Acta., 121:443-460.

[17] Ensafi A, Rezaei B, Movahedinia H. (2002) Kinetic-spectrophotometric determination of ascorbic acid by inhibition of the hydrochloric acid-bromate reaction. Spectrochim. Acta. A. Mol. Biomol. Spectrosc., 58:2589-94.

[18] Güçlü K, Sözgen K, Tütem E, Özyürek M, Apak R. (2005) Spectrophotometric determination of ascorbic acid using copper(II)-neocuproine reagent in beverages and pharmaceuticals. Talanta, 65:1226-32.

[19] Noroozifar M, Khorasani-Motlagh M. (2003) Solid-phase iodine as an oxidant in flow injection analysis: Determination of ascorbic acid in pharmaceuticals and foods by background correction. Talanta, 61:173-9.

[20] Dong YP, Gao TT, Chu XF, Chen J, Wang CM. (2014) Flow injection-chemiluminescence determination of ascorbic acid based on luminol-ferricyanide-gold nanoparticles system, J. Lumin., 154:350-355.

[21] Zhang G, He L, M.(2011) Optimized ultrasonic-assisted extraction of flavonoids from Prunella vulgaris L. and evaluation of antioxidant activities in vitro. Innovative Food Science and Emerging Technologies 12:18-25.

[22] Pan Y, Wang K, Huang S, Wang H, Mu X, He C, et al. (2008) Antioxidant activity of microwave-assisted extract of longan (Dimocarpus longan Lour.) peel. Food Chem., 106:1264-1270.

[23] Hayat K, Zhang X, Farooq U, Abbas S, Xia S, Jia C, et al. (2010) Effect of microwave treatment on phenolic content and antioxidant activity of citrus mandarin pomace. Food Chem.,123:423-429.

[24] Qu X, Fu Y, Luo M, Zhao C, Zu Y. (2013) Acidic pH based microwave-assisted aqueous extraction of seed oil from yellow horn (Xanthoceras sorbifolia Bunge.), Industrial Crops and Products, 43:420-426.

[25] Yang B, Zhao M, Shi J, Yang N, Jiang Y. (2008) Effect of ultrasonic treatment on the recovery and DPPH radical scavenging activity of polysaccharides from longan fruit pericarp. Food Chem., 106:685-690.

[26] Aybastıer Ö, Işı1k E, Şahin S, Demir C. (2013) Optimization of ultrasonic-assisted extraction of antioxidant compounds from blackberry leaves using response surface methodology. Ind. 
Crops Prod., 44:558-565.

[27] Ramandi NF, Ghassempour A, Najafi NM, Ghasemi E. (2012) Optimization of ultrasonic assisted extraction of fatty acids from Borago officinalis L. flower by central composite design. Arabian Journal of Chemistry.

[28] Huang W, Li Z, Niu H, Li D, Zhang J. (2008) Optimization of operating parameters for supercritical carbon dioxide extraction of lycopene by response surface methodology. J. Food Eng., 89:298-302.

[29] Passos CP, Silva RM, Da Silva FA, Coimbra MA, Silva CM. (2010) Supercritical fluid extraction of grape seed (Vitis vinifera L.) oil: Effect of the operating conditions upon oil composition and antioxidant capacity. Chem. Eng. J., 160:634-640.

[30] Mazzutti S, Ferreira SRS, Riehl CAS, Smania A, Smania FA, Martínez J. (2012) Supercritical fluid extraction of Agaricus brasiliensis: Antioxidant and antimicrobial activities. J. Supercrit. Fluids, 70:48-56.

[31] Wang L, Weller CL. (2006) Recent advances in extraction of nutraceuticals from plants. Trends Food Sci. Technol., 17:300-312.

[32] Kwiatkowska B, Bennett J, Akunna J, Walker GM, Bremner DH. (2011) Stimulation of bioprocesses by ultrasound. Biotechnol. Adv., 29:768-780.

[33] Suslick KS, Othmer K. (1998) Encyclopedia of Chemical Technology, 4th edn., J. Wiley \& Sons, New York.

[34] Mason T, Lorimer JP. (1998) Sonochemistry, theory, applications and uses of ultrasound in chemistry. Ellis Harwood Limited, Chichester West Sussex.

[35] Lee WC, Yusof S, Hamid NSA, Baharin BS. (2006) Optimizing conditions for hot water extraction of banana juice using response surface methodology (RSM). J. Food Eng., 75:473479.

[36] González-Montelongo R, Gloria Lobo M, González M. (2010) Antioxidant activity in banana peel extracts: Testing extraction conditions and related bioactive compounds. Food Chem., 119:1030-1039.

[37] Valdramidis V, Cullen P. (2010) Quantitative modelling approaches for ascorbic acid degradation and non-enzymatic browning of orange juice during ultrasound processing. Journal of Food Engineering, 96:449-454.

[38] Blasco R, Esteve MJ, Frígola A, Rodrigo M. (2004) Ascorbic acid degradation kinetics in mushrooms in a high-temperature short-time process controlled by a thermoresistometer, LWT. Food Sci. Technol., 37:171-175.

[39] Vieira MC, Teixeira AA, Silva CLM. (2000) Mathematical modeling of the thermal degradation kinetics of vitamin $\mathrm{C}$ in cupuacu (Theobroma grandiflorum) nectar. J. Food Eng., 43:1-7.

[40] Rathod SS, Rathod VK. (2014) Extraction of piperine from Piper longum using ultrasound. Ind. Crops Prod., 58:259-264.

[41] Tian Y, Xu Z, Zheng B, Martin Lo Y. (2013) Optimization of ultrasonic-assisted extraction of pomegranate (Punica granatum L.) seed oil. Ultrason. Sonochem., 20:202-208.

[42] Zhang H, Yang X, Zhao L, Wang Y. (2009) Ultrasonic-assisted extraction of epimedin C from fresh leaves of Epimedium and extraction mechanism. Innovative Food Science and Emerging Technologies, 10:54-60.

[43] Teng H, Choi YH. (2014) Optimization of ultrasonic-assisted extraction of bioactive alkaloid compounds from rhizoma coptidis (Coptis chinensis Franch.) using response surface methodology. Food Chem., 142:299-305.

[44] Shirsath SR, Sonawane SH, Gogate PR. (2012) Intensification of extraction of natural products using ultrasonic irradiations - A review of current status. Chem. Eng. Process. Process Intensif., 53:10-23.

[45] Becker EM, Nissen LR, Skibsted LH. (2004) Antioxidant evaluation protocols: Food quality or health effects. Eur. Food Res. Technol., 6:561-571.

[46] Liu J, Zheng S, Fan Q, Yuan J, Yang S. (2015) Optimisation of high-pressure ultrasonicassisted extraction and antioxidant capacity of polysaccharides from the rhizome of Ligusticum chuanxiong. Int. J. Biol. Macromol., 76:80-85.

[47] Pongmalai P, Devahastin S, Chiewchan N, Soponronnarit S. (2015) Enhancement of 
microwave-assisted extraction of bioactive compounds from cabbage outer leaves via the application of ultrasonic pretreatment. Sep. Purif. Technol., 144:37-45.

[48] Prakash Maran J, Manikandan S, Thirugnanasambandham K, Vigna Nivetha C, Dinesh R. (2013) Box-Behnken design based statistical modeling for ultrasound-assisted extraction of corn silk polysaccharide. Carbohydr. Polym., 92:604-611.

[49] Şahin S, Şamli R. (2013) Optimization of olive leaf extract obtained by ultrasound-assisted extraction with response surface methodology. Ultrason. Sonochem., 20:595-602.

[50] Liu X, Mu T, Sun H, Zhang M, Chen J. (2013) Optimisation of aqueous two-phase extraction of anthocyanins from purple sweet potatoes by response surface methodology. Food Chem., 141:3034-3041.

[51] Feng S, Luo Z, Tao B, Chen C. (2015) Ultrasonic-assisted extraction and purification of phenolic compounds from sugarcane (Saccharum officinarum L.) rinds, LWT. Food Sci. Technol., 60:970-976.

[52] Naczk M, Shahidi F. (2004) Extraction and analysis of phenolics in food. J. Chromatogr. A., 1054:95-111.

[53] Elksibi I, Haddar W, Ben Ticha M, Gharbi R, Mhenni MF. (2014) Development and optimisation of a non conventional extraction process of natural dye from olive solid waste using response surface methodology (RSM). Food Chem., 161:345-352.

[54] Ho CHL, Cacace JE, Mazza G. (2008) Mass transfer during pressurized low polarity water extraction of lignans from flaxseed meal. J. Food Eng., 89:64-71.

[55] H.M. Santos, C. Lodeiro, J.-L. Capelo-Martínez (2009), The Power of Ultrasound, Ultrasound in Chemistry: Analytical Applications. pp. 1-16.

[56] Mason TJ. (1992) Practical sonochemistry: Users guide to applications in chemistry and chemical engineering. Ellis Horwood Ltd, New York.

[57] Mason TJ. (2000) Sonochemistry. Oxford Chemistry Primers, Oxford, UK.

[58] Salisova M, Toma S, Mason TJ. (1997) Comparison of conventional and ultrasonically assisted extractions of pharmaceutically active compounds from Salvia officinalis. Ultrasonics sonochemistry, 4:131-134.

[59] Zhang Q, Zhang Z, Yue X, Fan X, Li T, Chen S. (2009) Response surface optimization of ultrasound-assisted oil extraction from autoclaved almond powder. Food Chemistry, 116: 513518.

[60] Herodez SS, Hadolin M, Skerget M, Knez Z. (2003) Solvent extraction study of antioxidants from balm (Melissa officinalis L.) leaves. Food Chemistry, 80:275-282. 